\title{
Kaolin from Acoculco (Puebla, Mexico) as raw material: Mineralogical and thermal characterization
}

\author{
M. GARCIA-VALLES ${ }^{1}$, T. PI ${ }^{2}$, P. ALFONSO ${ }^{3}$, C. CANET ${ }^{4}$, S. MARTÍNEZ $^{1}$, \\ A. JIMÉNEZ-FRANCO ${ }^{3,5}, \mathrm{M}$. TARRAGO ${ }^{1,{ }^{*}}$ AND B. HERNÁNDEZ-CRUZ ${ }^{5}$ \\ ${ }^{1}$ Dept. De Cristallografia, Mineralogia i Dipòsits Minerals, Facultat de Geologia, Universitat de Barcelona, \\ Carrer Martí i Franquès, S/n 08028 Barcelona, Spain \\ ${ }^{2}$ Instituto de Geología, Universidad Nacional Autónoma de México, Ciudad Universitaria, Delegación Coyoacán, \\ 04510 México, DF, Mexico \\ ${ }^{3}$ Dept. d'Enginyeria Minera i Recursos Naturals, Universitat Politécnica de Catalunya, Av. de les Bases de Manresa \\ 61-73, 08242 Manresa, Barcelona, Spain \\ ${ }^{4}$ Instituto de Geofisica, Universidad Nacional Autónoma de México, Ciudad Universitaria, Delegación Coyoacán, \\ 04510 México, DF, Mexico \\ ${ }^{5}$ Posgrado en Ciencias de la Tierra, Universidad Nacional Autónoma de México, Ciudad Universitaria, Delegación \\ Coyoacán, 04510 México, DF, Mexico
}

(Received 28 November 2014; revised 23 April 2015; Associate Editor: M. Plötze)

\begin{abstract}
The present study determined the mineralogy and thermal properties of kaolin from Acoculco (Puebla), at the eastern Trans-Mexican Volcanic Belt and compared it with the nearby deposits of Agua Blanca (Hidalgo) and Huayacocotla (Veracruz). The mineralogy of the kaolins was determined by X-ray diffraction, infrared spectroscopy and scanning electron microscopy. Thermal behaviour was studied by differential thermal analysis, dilatometry and hot-stage microscopy. The Acoculco deposit is composed mainly of kaolinite and $\mathrm{SiO}_{2}$ minerals. In the case of Agua Blanca and Huayacocotla, alunite is abundant in places and minor anatase is also present locally. The Acoculco kaolins are Fe-poor and relatively rich in some potentially toxic elements $(\mathrm{Zr}, \mathrm{Sb}, \mathrm{Pb})$. They undergo a relatively small amount of shrinkage ( $\sim 3-4$ vol.\%), during firing at $20-1300^{\circ} \mathrm{C}$ and cooling down to $20^{\circ} \mathrm{C}$, except when $>10 \mathrm{wt} . \%$ alunite is present. These kaolins are a suitable raw material for the ceramics industry. Other applications (pharmaceuticals, cosmetics) would require an enrichment process to eliminate impurities such as Fe oxides.
\end{abstract}

KeYwords: kaolinite, Mexico, mineralogy, thermal properties, shrinkage.

Kaolin is a clayey rock consisting mainly of kaolinite, $\mathrm{Al}_{2}\left(\mathrm{Si}_{2} \mathrm{O}_{5}\right)(\mathrm{OH})_{4}$. Kaolinite is characterized by an almost pure white colour, fine particle size $(\sim 1-2 \mu \mathrm{m})$, nontoxicity, very low abrasiveness and chemical stability. These properties make it a versatile mineral commodity with applications in a wide variety of industries. Impurities, particularly Fe oxides, reduce the potential

* E-mail:mtarrago@ub.edu

DOI: $10.1180 /$ claymin.2015.050.3.12 of kaolin for some applications, causing colour variations in the manufactured product (Saikia et al., 2003). Due to the emergence of new uses for nanocomposite materials, e.g. in ink for printers and in engineering and medicine (Schroeder \& Erickson, 2014), kaolins have attracted increased scientific and economic interest.

Kaolin deposits are widely distributed in Mexico, mainly in Chihuahua, Guanajuato, Veracruz, Michoacán and Hidalgo and are usually located in the Trans-Mexican Volcanic Belt (TMVB) (De PabloGalán, 1979). The exploitation of Mexican deposits, 
however, does not meet all of the country's needs and some of the kaolin needed has to be imported.

In the eastern part of the TMVB, in the states of Puebla, Hidalgo and Veracruz, there are several kaolin deposits and occurrences. The kaolins in Puebla occur in the Acoculco area, which is a volcanic caldera complex of geothermal interest composed mainly of volcanic acidic rocks that underwent pervasive hydrothermal alteration (Canet et al., 2010, 2015). The kaolinite is associated with alunite, opal, tridymite and anatase and is the product of advanced argillic alteration of tuffs and volcanic breccias (Canet et al., 2015).

The kaolin deposits of Acoculco have been the subject of sporadic exploitation, but they have never been studied previously. Agua Blanca, in Hidalgo and Huayacocotla, in Veracruz are two economically important, well known kaolin deposits (De PabloGalán, 1979) that occur near Acoculco (Fig. 1). The Agua Blanca kaolin has been studied in the past (Legorreta-García et al., 2010, 2013) and is currently under exploitation. The Huayacocotla deposit has been mined since 1952 and constitutes the main economic driver of the municipality of the same name.

The present study presents the first chemical, mineralogical and thermal characterization of the Acoculco kaolin deposits to evaluate possible applications and attempts to compare it with the kaolins of the Agua Blanca and Huayacocotla areas.

\section{GEOLOGICAL SETTING AND HYDROTHERMAL ALTERATION}

Since the early 1980s Acoculco has been considered a zone of geothermal interest by the Mexican stateowned electricity supplier Comisión Federal de Electricidad. Surface manifestations of geothermal activity, however, are scarce and consist of lowtemperature, bubbling, acid-sulfate springs that are concentrated in two areas separated from each other by $\sim 1750 \mathrm{~m}$. This zone is generally regarded as a candidate site for future hot-dry-rock development, although hydrothermal circulation has been ruled out (Canet et al., 2015 and references therein).

The Acoculco geothermal zone lies within the Acoculco volcanic caldera complex in the eastern TMVB, close to the 'Sierra Madre Oriental' geological province (Fig. 1). This complex contains up to $\sim 900 \mathrm{~m}$ of Pliocene to Pleistocene calcalkaline volcanic rocks (López-Hernández et al., 2009) overlying a Jurassic to Cretaceous sedimentary basement (Morales \& Garduño, 1984). The Acoculco caldera is $\sim 18 \mathrm{~km}$ in diameter and formed in response to two main periods of volcanic activity (López-Hernández et al., 2009). The older episode (3.0-2.6 Ma) produced mostly dacitic to rhyodacitic lavas and pyroclastic deposits, with an overall thickness of up to $\sim 600 \mathrm{~m}$. The second calderaforming episode occurred at 1.7-1.26 Ma producing rhyolitic domes, ignimbrite deposits and minor dacite lava flows, up to $300 \mathrm{~m}$ thick overall. Simultaneous with caldera formation, basaltic andesite was erupted outside the caldera structure. Younger basalts, erupted between 1.0 and $0.24 \mathrm{Ma}$, cover the earlier, felsic volcanic rocks (López-Hernández et al., 2009).

Most rocks of the Acoculco volcanic complex are tuffs, breccias and lavas that show pervasive hydrothermal alteration. There are two major zones of alteration affecting the subsurface rocks (Canet et al., 2010): (1) a shallow zone with ammonium illite; and (2) a deeper zone with a propylitic assemblage of epidote-calcite-chlorite. The shallow zone extends to a depth of 500-600 $\mathrm{m}$ below the ground surface and consists of pervasive ammonium-argillic alteration of the ignimbrites and lavas. The deeper zone was recognized down to at least $\sim 1000 \mathrm{~m}$ below the ground surface. In addition, silicic alteration is the most widespread type of alteration affecting the surficial rocks. This alteration occurs mostly as a pervasive replacement of the pyroclastic deposits and developed under temperature conditions below $\sim 150^{\circ} \mathrm{C}$ and nearneutral pH (Canet et al., 2015). Advanced argillic alteration at Acoculco is reflected in the kaolinite and sulfate-rich secondary mineral assemblages. This alteration may be the consequence of a steam-heated overprint in the geothermal system. Such overprints develop above the water table associated with the oxidation of $\mathrm{H}_{2} \mathrm{~S}$ in steam condensate, forming under low $\mathrm{pH}(2-3)$ at $\sim 100^{\circ} \mathrm{C}$ (e.g. White \& Hedenquist, 1995). Kaolinite-rich alteration occurs throughout the study area, whereas sulfates are intimately associated with areas of active gas manifestations.

Unlike Acoculco, the kaolin deposits at Agua Blanca and Huayacocotla are hosted in the sedimentary series of the 'Sierra Madre Oriental' (Fig. 1). They were formed by hydrothermal alteration related to volcanic activity of the TMBV (De Pablo-Galán, 1979).

\section{MATERIALS AND METHODS}

The kaolin samples studied were obtained from the Acoculco zone (Ac); in addition, representative samples from Huayacocotla (V) and Agua Blanca (H) were used for comparison purposes. Sixty nine sites of hydrothermally altered volcanic rocks were 
$97^{\circ} 44^{\prime} 56 \mathrm{E}$

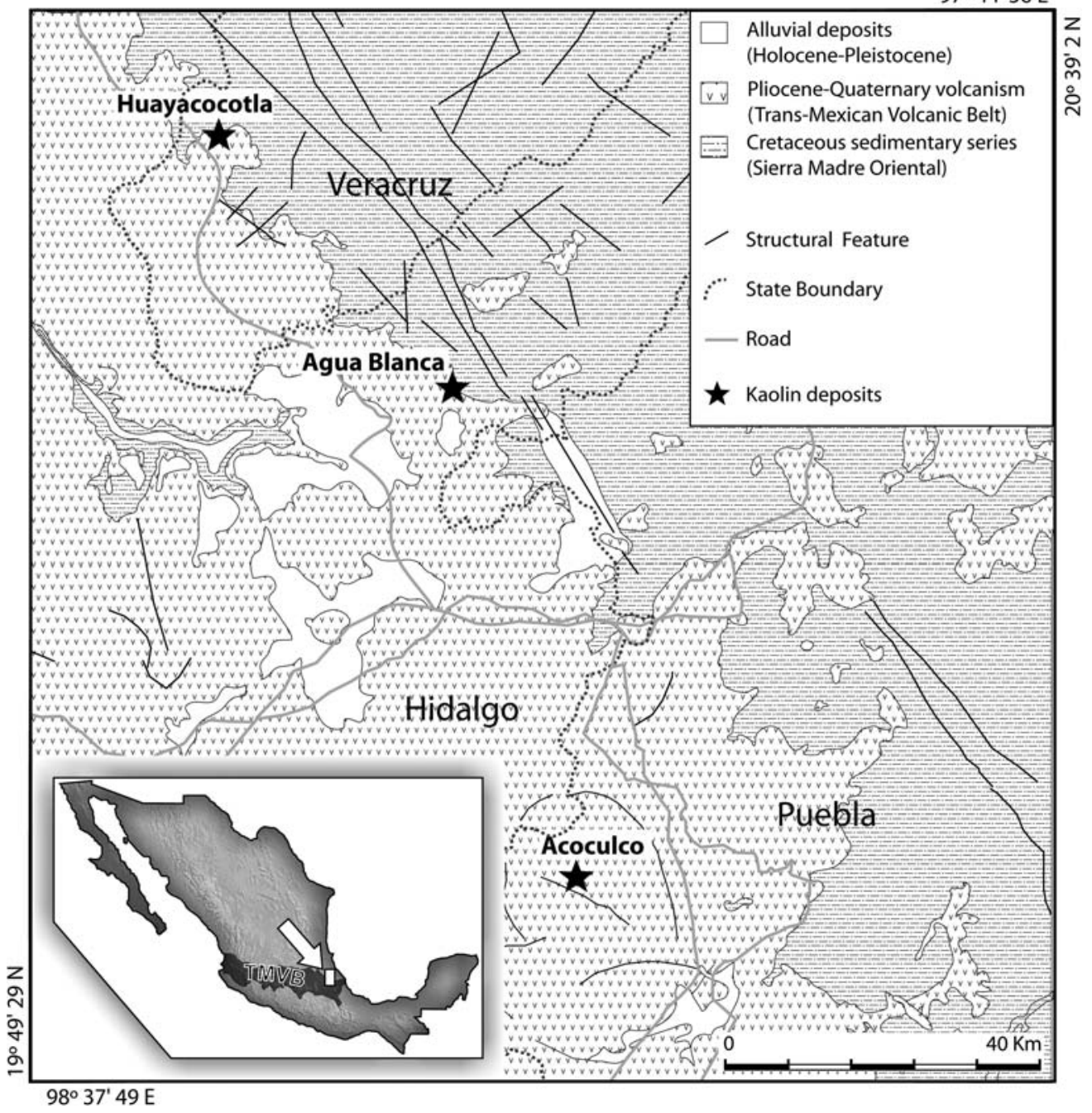

FIG. 1. Geological map of the study area showing the location of the kaolin deposits.

examined in Acoculco, distributed over an area of $8 \mathrm{~km} \times 10 \mathrm{~km}$ at the centre of the volcanic complex (cf. Canet et al., 2015). Kaolinite was first detected by short-wave infrared (SWIR) reflectance spectroscopy (Spectral International Inc., 1994) in 15 of the sampled sites (Canet et al., 2015); among these, two occurrences were selected based on their purity and the extent of the outcrops: Ac1 (19 $55^{\prime} 39.06^{\prime \prime} \mathrm{N} / 98^{\circ} 10^{\prime}$ 6.12" O) and Ac2 (19 $\left.54^{\prime} 13.98^{\prime \prime} \mathrm{N} / 98^{\circ} 10^{\prime} 38.10^{\prime \prime} \mathrm{O}\right)$.

The SWIR reflectance spectroscopic study was carried out using a portable LabSpec Pro Spectrophotometer (Analytical Spectral Devices, Inc.). Visible and NIR reflectance of samples, for the spectral range between 350 and $2500 \mathrm{~nm}$ (with a sampling interval of $2 \mathrm{~nm}$ at $0.1 \mathrm{~s}$ per scan), were measured using an internal light source and sensor. Samples were examined spectrally in the laboratory, without any further pre-treatment (e.g. crushing and powdering) prior to spectra collection.

Bulk chemical analyses were performed to determine major- and trace-element concentrations. The major-elements composition was obtained using a Panalytical, Axios PW 4400/40 sequential wavelength-dispersive X-ray fluorescence spectrophotometer (WDXRF), whereas the concentrations of trace elements were determined by inductively coupled plasma mass spectrometry (ICP-MS), using a PerkinElmer Elan-6000 ICP-MS spectrometer. 
The mineralogy was determined by X-ray powder diffraction (XRD) and SWIR reflectance spectroscopy. For XRD analyses, oriented and random mounted samples were prepared. Random samples were examined using back-loading aluminium holders. The XRD patterns were obtained for oriented specimens after the following pre-treatments: air drying at room temperature, saturation with ethylene glycol and after heating at $400^{\circ} \mathrm{C}$ and $550^{\circ} \mathrm{C}$ for $1 \mathrm{~h}$ (Moore \& Reynolds, 1997). The XRD measurements were performed with a Shimadzu XRD-6000 diffractometer operating with an accelerating voltage of $40 \mathrm{kV}$ and a filament current of $30 \mathrm{~mA}$, using $\mathrm{Cu} K \alpha$ radiation and a graphite monochromator. All the preparations were measured over a $2 \theta$ angle range of $2-70^{\circ}$ at a scanning speed of $1^{\circ} 2 \theta / \mathrm{min}$. Phase identification was made with the PDF-2 database using the Shimadzu software. Rietveld refinement of the data was performed on XRD patterns of randomly oriented samples using the TOPAS Academic v.4.1 software (Cheary \& Coelho, 1992).

Back-scattered electron images and qualitative chemical analyses of the kaolin samples were obtained using an Hitachi TM-1000 table-top scanning electron microscope (SEM) equipped with an energy dispersive $\mathrm{X}$-ray spectrometer (EDS).

Thermal analysis of the kaolin samples was studied by simultaneous differential thermal analysis and thermogravimetry (DTA-TG), using a Netzsch instrument (STA 409C model). Analyses were carried out in the temperature range $25-1300^{\circ} \mathrm{C}$ under air atmosphere, at a constant flow rate of $80 \mathrm{~mL} / \mathrm{min}$, in an alumina $\left(\mathrm{Al}_{2} \mathrm{O}_{3}\right)$ crucible and at a heating rate of $10^{\circ} \mathrm{C} / \mathrm{min}$. The amount of sample analysed was $\sim 60 \mathrm{mg}$.

The dilatometric curves were measured using a Linseis dilatometer L76/1550. The experiment was carried out from room temperature to $1300^{\circ} \mathrm{C}$ at a heating rate of $10^{\circ} \mathrm{C} / \mathrm{min}$, in a static-air atmosphere. Hot-stage microscopy (HSM) was used to study mineral behaviour in melting processes. Three $1 \mathrm{~mm}$ high test cylinders of the kaolin samples were shaped with powders of $<45 \mu \mathrm{m}$ in size and a $1 / 20$ solution of Elvacite ${ }^{\circledR}$ in acetone, in a uniaxial press. The test cylinders were heated at a rate of $5^{\circ} \mathrm{C} / \mathrm{min}$ from room temperature to $1450^{\circ} \mathrm{C}$ in air atmosphere. The whole process was recorded in pictures using ProgRes Capture Pro 2.8 software (Jentoptik, Germany). Analysis was performed with the Hot-Stage software, developed by the Departament de Llenguatges $i$ Sistemes Informàtics, ETSEIB, UPC (Garcia-Valles et al., 2013).

\section{RESULTS AND DISCUSSION}

\section{Chemical and mineralogical characterization}

The chemical compositions of the samples are presented in Table 1. The $\mathrm{SiO}_{2}$ content ranges from 40.41 to 57.57 wt.\% except for one sample from Acoculco (70.41 wt.\%). The $\mathrm{Al}_{2} \mathrm{O}_{3}$ content varies between 18.67 and $34.66 \mathrm{wt} . \%$. The alkali content is very small in the three deposits studied, with $\mathrm{Na}_{2} \mathrm{O}$ ranging between 0.02 and 0.18 wt. $\%$ and $\mathrm{K}_{2} \mathrm{O}$ between 0.07 and 0.65 wt. $\%$, with the exception of one sample from the Huayacocotla area $\left(1.72\right.$ wt. $\left.\% \mathrm{~K}_{2} \mathrm{O}\right)$.

The $\mathrm{Fe}_{2} \mathrm{O}_{3}$ content of the Acoculco kaolins is very small, ranging between 0.09 and $0.17 \mathrm{wt} . \%$, whereas in those from Huayacocotla and Agua Blanca it ranges between 0.36 and 1.20 wt. $\%$. $\mathrm{TiO}_{2}$ is usually $<1 \mathrm{wt} . \%$, except in one sample from Acoculco which contains 2.63 wt. $\%$.

The XRD patterns of the kaolins studied are shown in Fig. 2. Kaolinite is the dominant mineral at all locations (Table 2) and in Acoculco it reaches almost 90 wt.\%. Si polymorphs (quartz, tridymite and cristobalite) are also abundant, ranging between 6 and 40 wt.\%. Alunite $\mathrm{KAl}_{3}\left(\mathrm{SO}_{4}\right)_{2}(\mathrm{OH})_{6}$ occurs in small amounts in Acoculco, whereas it may reach up to 10 wt.\% in Agua Blanca and 18 wt.\% in Huayacocotla. Sample Ac1, from Acoculco, which is the richest in Ti (2.63 wt.\% of $\mathrm{TiO}_{2}$ according to the WDXRF results), contains $\sim 3 \mathrm{wt} . \%$ of anatase according to the XRD results. Anatase is a common mineral in kaolin deposits (Baioumy, 2014). Microanalysis by SEMEDS confirmed that titanium mostly occurs in the form of a pure Ti oxide phase, although some Ti-Fe oxide crystals, probably ilmenite, are also present. Based on the peak heights in the oriented XRD patterns, the occurrence of true kaolinite or dehydrated halloysite was estimated using the ratios between the $7.2 \AA$ and $4.4 \AA$ peaks; the latter, being a non-basal maximum, is high for halloysite and weak for kaolinite (Dixon \& Weed, 1989). These measurements confirm that kaolinite is the predominant phase.

The SWIR reflectance spectra of the kaolinite studied are characterized by two absorption doublets; one at 2158 and $2205 \mathrm{~nm}$ and another at 1395 and $1408 \mathrm{~nm}$ (Fig. 3). The former corresponds to the $\mathrm{Al}-\mathrm{OH}$ bond and the latter to $\mathrm{OH}$ and molecular $\mathrm{H}_{2} \mathrm{O}$ vibrations.

The morphology of the clay particles reveals regular or elongated lamellar hexagonal flakes of kaolinite, often grouped in booklets (Fig. 4). The platy euhedral (non-tubular) morphology of crystals in the SEM images is a common characteristic of low-defect 
TABLE 1. Major and trace-elements contents of representative samples from the Acoculco (Ac), Huayacocotla (V) and Agua Blanca $(\mathrm{H})$ deposits.

\begin{tabular}{|c|c|c|c|c|c|}
\hline Oxide/Metal & Ac1 & Ac2 & V1 & H1 & $\mathrm{H} 2$ \\
\hline \multicolumn{6}{|l|}{ Wt.\% } \\
\hline $\mathrm{SiO}_{2}$ & 57.57 & 70.41 & 40.41 & 56.62 & 53.73 \\
\hline $\mathrm{Al}_{2} \mathrm{O}_{3}$ & 26.99 & 18.67 & 34.66 & 29.22 & 28.86 \\
\hline $\mathrm{Fe}_{2} \mathrm{O}_{3}$ & 0.09 & 0.17 & 0.67 & 0.36 & 1.20 \\
\hline $\mathrm{MgO}$ & 0.01 & 0.02 & - & 0.02 & 0.03 \\
\hline $\mathrm{CaO}$ & 0.18 & 0.07 & 0.02 & 0.05 & 0.08 \\
\hline $\mathrm{Na}_{2} \mathrm{O}$ & 0.02 & 0.18 & 0.09 & 0.04 & 0.10 \\
\hline $\mathrm{K}_{2} \mathrm{O}$ & 0.16 & 0.07 & 1.72 & 0.24 & 0.65 \\
\hline $\mathrm{TiO}_{2}$ & 2.63 & 0.65 & 0.60 & 0.48 & 0.98 \\
\hline $\mathrm{P}_{2} \mathrm{O}_{5}$ & 0.39 & 0.10 & 0.08 & 0.12 & 0.17 \\
\hline LOI & 11.22 & 8.3 & 19.99 & 12.19 & 14.01 \\
\hline Total ppm & 99.25 & 98.65 & 98.26 & 99.35 & 99.82 \\
\hline $\mathrm{Sc}$ & 56 & 5 & 14 & 13 & 19 \\
\hline V & 168 & 31 & 36 & 39 & 54 \\
\hline $\mathrm{Cr}$ & 50 & - & - & - & 30 \\
\hline $\mathrm{Ga}$ & 8 & 24 & 82 & 44 & 62 \\
\hline $\mathrm{Ge}$ & 2.2 & 1.9 & 0.9 & 1.2 & 1.2 \\
\hline As & 9 & - & - & - & - \\
\hline $\mathrm{Rb}$ & 2 & 3 & 15 & 2 & 6 \\
\hline $\mathrm{Sr}$ & 302 & 230 & 85 & 136 & 215 \\
\hline $\mathrm{Y}$ & 76.9 & 33.7 & 19.8 & 23 & 33.9 \\
\hline $\mathrm{Zr}$ & 332 & 573 & 757 & 576 & 958 \\
\hline $\mathrm{Nb}$ & 20.2 & 26.3 & 55.7 & 42.4 & 54.7 \\
\hline Mo & - & 3 & 4 & 2 & 4 \\
\hline $\mathrm{Ag}$ & 1.2 & 2.5 & 11 & 7.5 & 12.8 \\
\hline Sn & 4 & 3 & 10 & 8 & 10 \\
\hline $\mathrm{Sb}$ & 30.1 & 1.5 & 0.8 & 1.9 & 1.3 \\
\hline Cs & - & 0.4 & 0.2 & 0.2 & 0.4 \\
\hline $\mathrm{Ba}$ & 320 & 257 & 406 & 366 & 949 \\
\hline $\mathrm{La}$ & 31.4 & 40 & 83.3 & 104 & 129 \\
\hline $\mathrm{Ce}$ & 79.5 & 88.5 & 129 & 187 & 245 \\
\hline $\operatorname{Pr}$ & 11.1 & 10.1 & 13.7 & 21.4 & 28.5 \\
\hline $\mathrm{Nd}$ & 52.7 & 37.9 & 43.1 & 76.2 & 97.7 \\
\hline $\mathrm{Sm}$ & 14.0 & 7.6 & 7.2 & 14.6 & 16.8 \\
\hline $\mathrm{Eu}$ & 3.8 & 1.3 & 0.8 & 1.2 & 1.7 \\
\hline $\mathrm{Gd}$ & 12.2 & 6.1 & 5.3 & 11.3 & 11.5 \\
\hline $\mathrm{Tb}$ & 2.4 & 1.1 & 0.7 & 1.3 & 1.4 \\
\hline Dy & 16.2 & 6.4 & 4.1 & 5.8 & 7.1 \\
\hline Ho & 3.2 & 1.3 & 0.8 & 1.0 & 1.4 \\
\hline $\mathrm{Er}$ & 8.6 & 4.1 & 2.4 & 2.6 & 4.4 \\
\hline $\mathrm{Tm}$ & 1.2 & 0.6 & 0.4 & 0.4 & 0.8 \\
\hline $\mathrm{Yb}$ & 7.4 & 4.6 & 2.9 & 2.8 & 5.6 \\
\hline $\mathrm{Lu}$ & 1.2 & 0.8 & 0.5 & 0.5 & 0.9 \\
\hline Hf & 7 & 12.3 & 20.6 & 15.7 & 22.7 \\
\hline $\mathrm{Ta}$ & 1.4 & 2.1 & 3.9 & 3.1 & 3.8 \\
\hline W & - & 1.6 & 1.5 & 1.6 & 1.5 \\
\hline $\mathrm{Pb}$ & - & 11 & 45 & 34 & 41 \\
\hline
\end{tabular}


TABLE 1. (contd.)

\begin{tabular}{lccccr}
\hline Oxide/Metal & Ac1 & Ac2 & V1 & H1 & H2 \\
\hline Bi & 0.6 & - & 0.3 & 0.2 & 0.1 \\
Th & 3.6 & 12.3 & 34.3 & 38.3 & 37.6 \\
U & 1.3 & 4.0 & 4.37 & 7 & 5.8 \\
\hline
\end{tabular}

kaolinite and confirms the absence of halloysite. The ranges of kaolinite 'crystallinity' indexes were measured (Hinkley, HI and AGFI) and confirm its high crystal order (Table 3).

The mineralogical characterization is consistent with the chemical analysis of the kaolins. The sample with large $\mathrm{SiO}_{2}$ content contains 40 wt.\% of cristobalite (sample Ac2, Tables 1 and 2). By subtracting the silica contribution from cristobalite, the $\mathrm{SiO}_{2}$ and $\mathrm{Al}_{2} \mathrm{O}_{3}$ contents are of $\sim 50$ and $\sim 30 \mathrm{wt} . \%$, respectively; this composition is roughly in accordance with that of kaolinite.
Even at low concentrations in the raw material, iron can cause problems in the whiteness of ceramics if titanium is present in significant amounts, because dark-coloured Fe-Ti minerals may form after firing. This should be taken into account when evaluating the final colour of the ceramics. However, although Ti in Acoculco is present in large amounts (up to $2.63 \mathrm{wt} . \%$ ), it does not influence the final colour of the ceramics due to the small $\mathrm{Fe}$ content (up to 0.17 wt. $\% \mathrm{Fe}_{2} \mathrm{O}_{3}$ ). This is a very promising result, as kaolins currently mined in Mexico are rich in chromophore elements making it difficult to obtain white products (Vazquez et al., 2009).

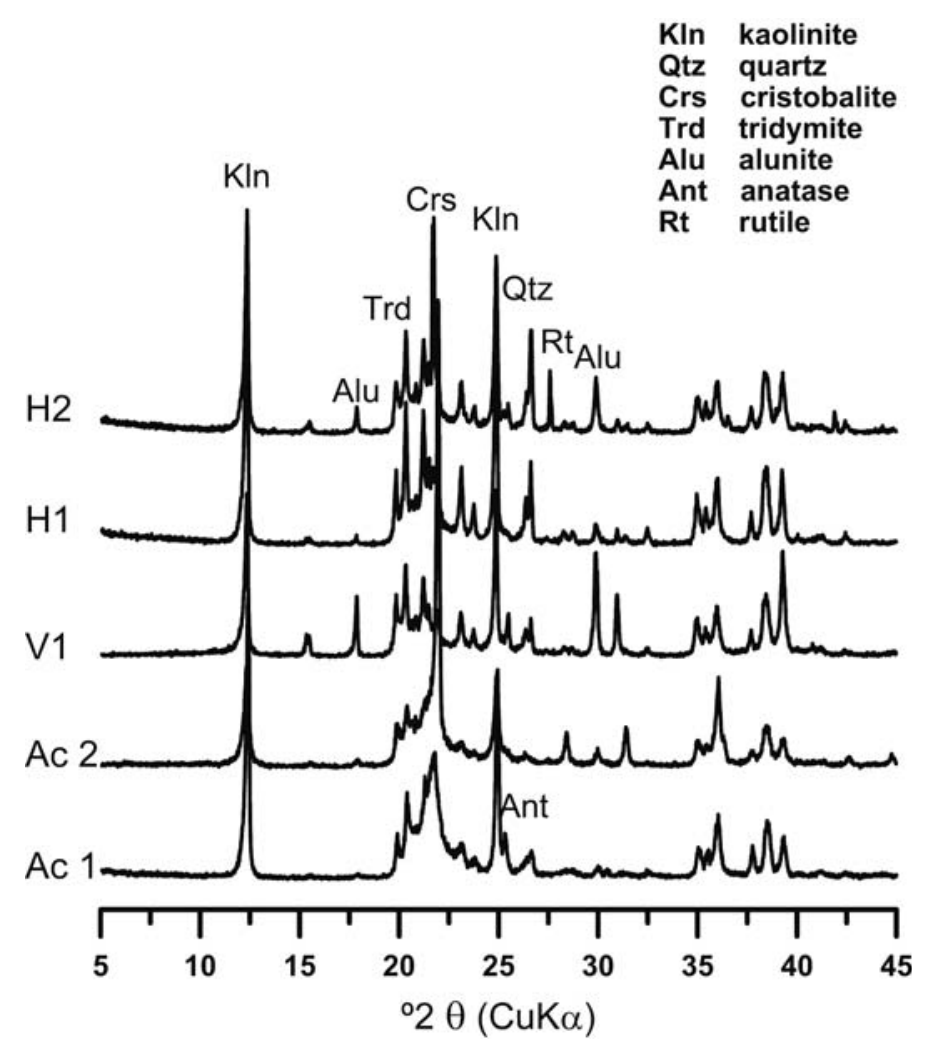

FIG. 2. XRD patterns of the studied kaolin from random oriented mounts. Ac, Acoculco (Puebla); V, Huayacocotla (Veracruz); H, Agua Blanca (Hidalgo). The y-axis represents the relative intensity of counts. 
TABLE 2. Mineralogical composition of the kaolins studied obtained using XRD. The uncertainty in the wt. $\%$ of each phase is expressed as $3 \sigma$, calculated using the TOPAS Academic Software.

\begin{tabular}{lccccc}
\hline Mineral phases (wt.\%) & Ac1 & Ac2 & V1 & H1 & H2 \\
\hline Kaolinite & $87( \pm 2)$ & $57( \pm 3)$ & $76( \pm 2)$ & $81( \pm 4)$ & $70( \pm 4)$ \\
Quartz & - & - & $2( \pm 2)$ & $2( \pm 1)$ & $3( \pm 1)$ \\
Cristobalite & $8( \pm 2)$ & $40( \pm 3)$ & $4( \pm 1)$ & $6( \pm 1)$ & $3( \pm 2)$ \\
Tridymite & - & - & - & $9( \pm 1)$ & $13( \pm 4)$ \\
Alunite & $2( \pm 1)$ & $3( \pm 1)$ & $18( \pm 1)$ & $2( \pm 1)$ & $10( \pm 1)$ \\
Rutile & - & - & - & - & $1( \pm 1)$ \\
Anatase & $3( \pm 1)$ & - & - & - & - \\
& & & & & \\
\hline
\end{tabular}

The trace-elements contents in the kaolins studied are not large but, in some cases, exceed the amounts of potentially toxic elements (PTE) permitted by the European Community regulation 1223/2009, according to which $\mathrm{As}, \mathrm{Cr}, \mathrm{Sb}, \mathrm{Pb}$ and $\mathrm{Zr}$ can be tolerated only at very small concentrations for use in cosmetics (Silva et al., 2011) and in pharmacological applications (e.g. $\mathrm{Pb}<10$ ppm; López-Galindo et al., 2007). All the kaolins analysed are rich in $\mathrm{Zr}$ (332-958 ppm). In Acoculco, the $\mathrm{Sb}$ content is as much as $30 \mathrm{ppm}$. The $\mathrm{Pb}$ content in Acoculco (0-11 ppm) is lower than in the Agua Blanca and Huayacocotla deposits (34-45 ppm).

\section{Thermal behaviour}

The results of the dilatometric analysis are listed in Table 4 and shown in Fig. 5. The overall shrinkage, measured from 20 to $1300^{\circ} \mathrm{C}$ and under subsequent cooling to $20^{\circ} \mathrm{C}$, of samples from Acoulco and of one from Agua Blanca ( $\mathrm{H} 1)$, is comparable and very limited, varying between 3.0 and 4.5 vol.\%. Limited shrinkage is a very important feature for raw materials used in ceramic processes, as it reduces contractions and therefore stresses that may occur during firing. The kaolin sample from Huayacocotla and one from Agua Blanca (V1 and H2, respectively) undergo a larger shrinkage, $\sim 10$ vol.\% (Fig. 5), attributed to their greater alunite contents (Table 2). The presence of alunite causes different thermal behaviour due to the six water molecules in its structure and the release of $\mathrm{SO}_{3}$ during alunite decomposition at $680^{\circ} \mathrm{C}$ (Frost et al., 2006). In all cases the dilatometric curves start with a soft and regular expansion with temperature rise. In samples $\mathrm{H} 1$ and Ac2 the trace presents a shallow expansion

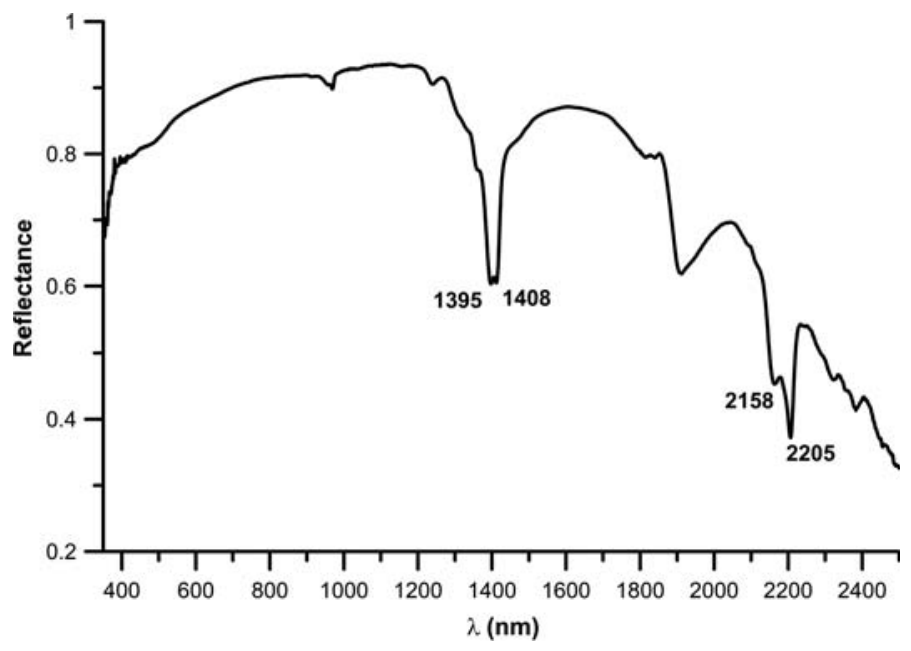

FIG. 3. SWIR spectrum of a representative kaolin from Accoculco (sample Ac1). 

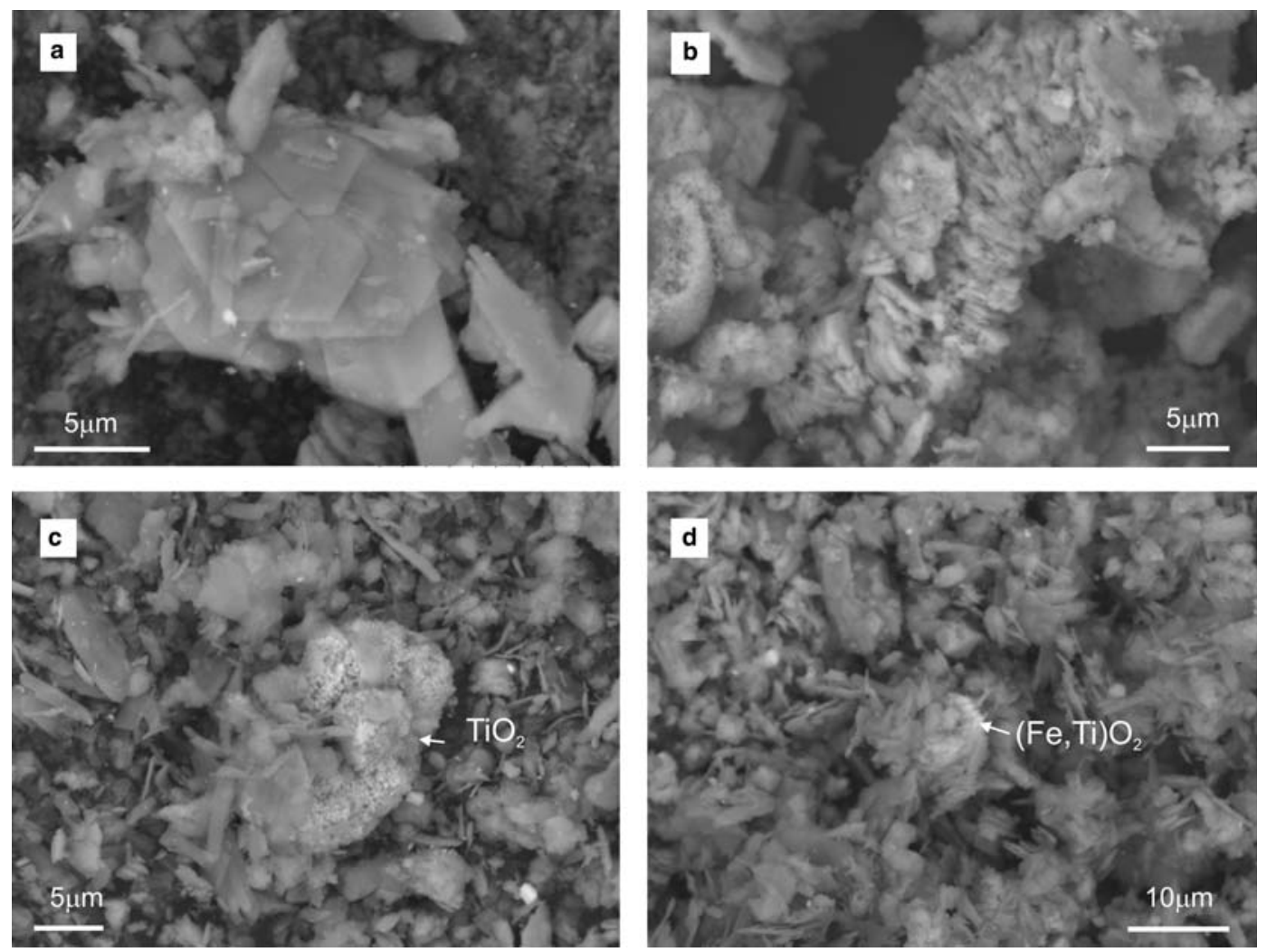

FIG. 4. SEM images of a representative kaolin sample from the Acoculco deposit: (a) kaolinite platelets from Acoculco; (b) kaolinite booklets from the Huaynacocotla deposit of Veracruz; (c) kaolinite from Acoculco accompanied by a Tioxide crystal; and (d) kaolinite from Acoculco with an Fe-Ti oxide.

beginning at $186^{\circ} \mathrm{C}$ and $210^{\circ} \mathrm{C}$ and an intensity of 0.2 and $0.4 \%$, respectively, attributed to the $\alpha-\beta$ cristobalite transformation. This is consistent with the cristobalite content of these samples (Table 2). Shrinkage begins at $\sim 550^{\circ} \mathrm{C}$ in all samples with different intensity, $0.9 \%$ for samples $\mathrm{V} 1$ and $\mathrm{H} 2$ and $0.3-0.4 \%$ for the others. This event corresponds to the loss of $\mathrm{OH}$ groups during the dehydroxylation of kaolinite and the formation of metakaolinite. The volume continues to decrease. The next shrinkage step by 0.5 to 1.5 vol.\% (sample V1) above $\sim 800^{\circ} \mathrm{C}$ was produced by the collapse of metakaolinite into a spinel-like structure (Chakravorty

TABLE 3. Values of the AGFI (Aparicio et al., 2006) and HI (Hinckley, 1963) indexes of kaolinite in the kaolin samples studied.

\begin{tabular}{lcccc}
\hline Sample & HI & AGFI & Crystallinity degree & Crystallite Size (Debye-Scherrer) (nm) \\
\hline Ac1 & 1.30 & 1.48 & Low-defect Kaolinite & 91 \\
Ac2 & 1.71 & 2.09 & Low-defect Kaolinite & 190 \\
V1 & 1.13 & 1.28 & Low-defect Kaolinite & 139 \\
H1 & 1.56 & 1.84 & Low-defect Kaolinite & 221 \\
H2 & 1.37 & 1.62 & Low-defect Kaolinite & 172 \\
\hline
\end{tabular}


TABLE 4. Temperatures and shrinkage in the reactions produced during firing.

\begin{tabular}{|c|c|c|c|c|c|c|c|c|}
\hline \multirow[b]{2}{*}{ Sample } & \multicolumn{2}{|c|}{$\alpha-\beta$ cristobalite } & \multicolumn{2}{|c|}{$\begin{array}{l}\text { Dehydroxylation } \\
\text { of kaolinite }\end{array}$} & \multicolumn{2}{|c|}{$\begin{array}{l}\text { Transformation } \\
\text { into spinel-like } \\
\text { structure }\end{array}$} & \multirow{2}{*}{$\begin{array}{l}\text { Mullite formation } \\
\text { and sintering }\left({ }^{\circ} \mathrm{C}\right)\end{array}$} & \multirow{2}{*}{$\begin{array}{l}\text { Vol.\% shrinkage } \\
20-1300-20^{\circ} \mathrm{C}\end{array}$} \\
\hline & $\% \Delta \mathrm{L}$ & $T_{\text {start }}\left({ }^{\circ} \mathrm{C}\right)$ & $\% \Delta \mathrm{L}$ & $T_{\text {start }}\left({ }^{\circ} \mathrm{C}\right)$ & $\% \Delta \mathrm{L}$ & $T_{\text {start }}\left({ }^{\circ} \mathrm{C}\right)$ & & \\
\hline $\mathrm{Ac} 1$ & - & - & 0.3 & 575 & 0.5 & 882 & 1091 & 4.5 \\
\hline Ac2 & 0.4 & 210 & 0.4 & 566 & 0.4 & 728 & 1038 & 3.1 \\
\hline V1 & - & - & 0.9 & 555 & 1.5 & 870 & 1051 & 10.5 \\
\hline H1 & 0.2 & 186 & 0.3 & 546 & 0.6 & 709 & 1134 & 3.7 \\
\hline $\mathrm{H} 2$ & - & - & 0.9 & 539 & 0.5 & 875 & 1090 & 10.2 \\
\hline
\end{tabular}

\& Ghosh, 1991; Ramachandran et al., 2002). Finally, above $\sim 1050^{\circ} \mathrm{C}$ the spinel-like phase is transformed to mullite; the sintering of the material starts during the mullitization stage.

In comparing the alunite-rich samples ( $\mathrm{H} 2, \mathrm{~V} 1), \mathrm{H} 2$ displays less shrinkage and is more dimensionally stable, due to its larger silica content. The kaolin from Acoculco shows less shrinkage than its counterparts from the other regions; sample Ac1, which is the richest in kaolinite and has the smallest alunite and silica contents, displays maximum shrinkage. On the other hand, Ac2 show less shrinkage because of its relatively high silica content. In this case, the large amount of cristobalite must be taken into account for the design of the firing curve of the ceramic paste in order to anticipate shrinkages and expansions, due to the $\alpha-\beta$ transformation of cristobalite at $\sim 200^{\circ} \mathrm{C}$. When kaolin is used as a raw material in the ceramics industry, combined with other materials, the behaviour of the paste during firing will be influenced by all of the components. Thus, characterization of different kaolins will enable determination of their contribution to the firing process.

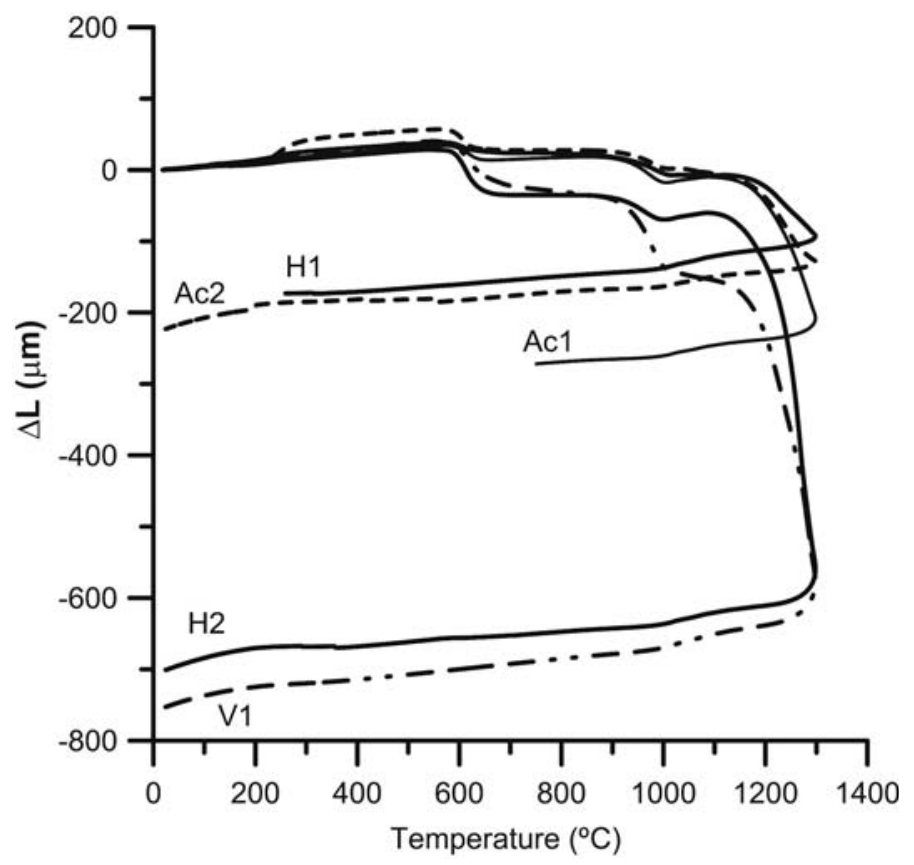

FIG. 5. Dilatometric curves of the kaolin studied. 
TABLE 5 . Thermal events measured by DTA in the temperature range $25-1300^{\circ} \mathrm{C}$.

\begin{tabular}{lcccc}
\hline Sample & Endo $\left({ }^{\circ} \mathrm{C}\right)$ & Endo $\left({ }^{\circ} \mathrm{C}\right)$ & Endo $\left({ }^{\circ} \mathrm{C}\right)$ & Exo $\left({ }^{\circ} \mathrm{C}\right)$ \\
\hline Ac1 & 321 & 550 & - & 993 \\
Ac2 & - & 527 & - & 999 \\
V1 & 232 & 554 & 768 & 992 \\
H1 & 225 & 542 & - & 996 \\
H2 & 215 & 541 & 745 & 987 \\
\hline
\end{tabular}

Dilatometric curves are used to determine the dimensional behaviour of the green body during firing. When considering the possible applications of kaolins in the manufacture of ceramics, it is important to know the temperature and the shrinkage that occur at each reaction produced during firing, the temperature at which sintering begins and the percentage of shrinkage in dry-firing conditions (Table 4).

The sintering process starts at between 1038 and $1134^{\circ} \mathrm{C}$. The HSM analysis shows that this process continues to temperatures $>1450^{\circ} \mathrm{C}$. The formation of a liquid phase and expansion of the sample were not observed at this temperature. The sintering degree is also related to the alunite contents.

The results from DTA of the samples are summarized in Table 5 and the DTA curves are shown in Fig. 6. The first event in the DTA curves is a broad endothermic peak, at $\sim 230^{\circ} \mathrm{C}$, which is attributed to the decomposition of poorly crystalized fine-grained aluminium hydroxide (Smykatz-Kloss, 1974). The degree of crystal order of the aluminium phases can modify decomposition temperatures, in comparison to the corresponding crystalline materials (SmykatzKloss, 1974). The second event is an endothermic peak at $\sim 530-550^{\circ} \mathrm{C}$, corresponding to the dehydroxylation of kaolinite and decomposition of alunite to $\mathrm{KAl}\left(\mathrm{SO}_{4}\right.$ ), amorphous $\mathrm{Al}_{2} \mathrm{O}_{3}$ and $\mathrm{H}_{2} \mathrm{O}$ (Küçük \& Gülaboğlu, 2002). The exothermal peak at $\sim 990$ $1000^{\circ} \mathrm{C}$ is attributed to mullite crystallization. In the kaolin with large alunite content, an additional endothermic event appears at between 745 and $768^{\circ} \mathrm{C}$, which is attributed to the decomposition of $\mathrm{KAl}\left(\mathrm{SO}_{4}\right)_{2}$ to $\mathrm{K}_{2} \mathrm{SO}_{4}, \mathrm{Al}_{2} \mathrm{O}_{3}$ and $\mathrm{SO}_{3}$ (Kakali et al., 2001).

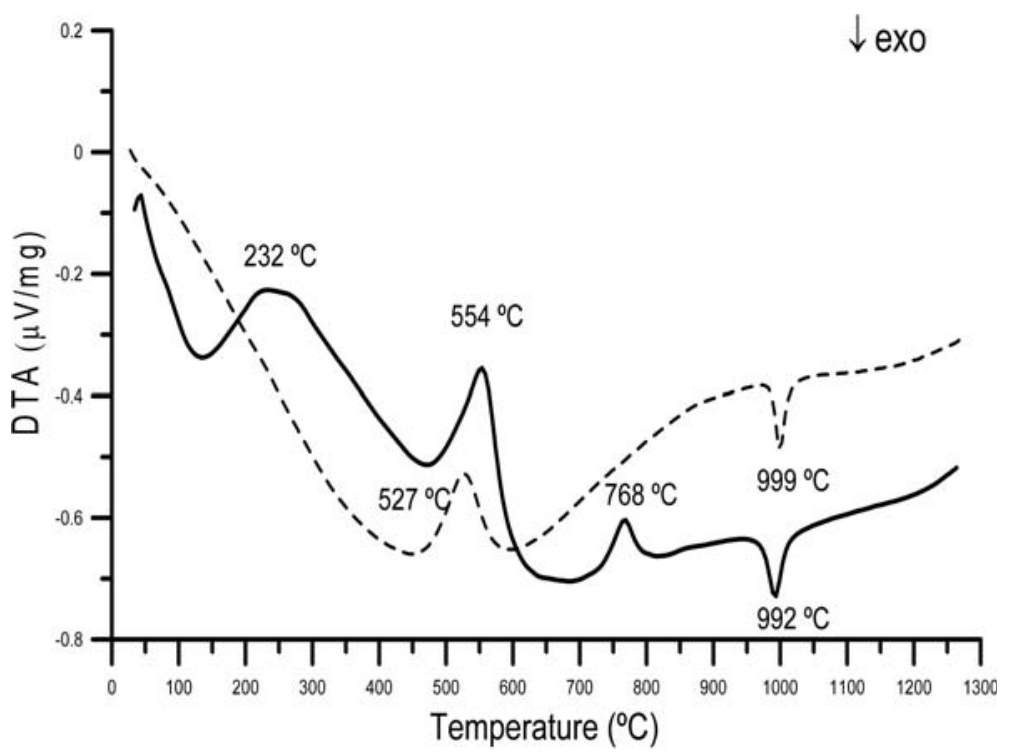

FIG. 6. DTA curves of kaolin from: Acoculco (Ac1, dashed line), which corresponds to a typical kaolinite; and, Huayacocotla (V1, continuous line) showing thermal events related to kaolinite and alunite. 


\section{CONCLUSIONS}

The mineralogical and chemical characteristics of the kaolins studied, especially their relatively small iron contents (0.67-0.09 wt.\% $\left.\mathrm{Fe}_{2} \mathrm{O}_{3}\right)$, and the absence of an enrichment process, indicates that the most suitable application for these clays is probably in the ceramics industry. For use in other applications, such as the cosmetics and pharmaceutical industries, the kaolins should undergo enrichment, in order to eliminate impurities such as $\mathrm{SiO}_{2}$ polymorphs.

The large $\mathrm{SiO}_{2}$ polymorphs contents in the Acoculco kaolin prevent their use in several applications, such as the paper and cosmetics industry. That factor is positive, however, for other applications, such as in the ceramics industry, because a certain amount of $\mathrm{SiO}_{2}$ is present in ceramic pastes. The $\mathrm{SiO}_{2}$ phases must be controlled, however, to prevent the $\alpha-\beta$ transformation of cristobalite during the firing process that may produce expansions and shrinkages in the ceramic pieces. Finally, the contents of some PTE in the Acoculco kaolins are too large for use in pharmaceutical and cosmetic applications.

Besides modifying the thermal behaviour of kaolins, alunite greatly increases the shrinkage of the raw material. Minor variations of shrinkage can be explained by the ratio of kaolinite to $\mathrm{SiO}_{2}$ minerals. Samples richer in kaolinite will shrink more than samples with greater $\mathrm{SiO}_{2}$ minerals contents. The Acoculco kaolins typically exhibit relatively little shrinkage $(\sim 3-4 \%)$, which makes them suitable for the applications in ceramics.

\section{ACKNOWLEDGEMENTS}

The authors thank the staff of the Scientific-Technical Service Unit of the University of Barcelona (CCiTUB) for their technical support. This study was carried out in the framework of the Consolidated Group 2014 SGR-1661 (Recursos Minerals: jaciments, aplicacions, sostenibilitat). Financial support was provided by the Fundació Bosch $i$ Gimpera Project 307466, by the Mexican projects 151453 (Fondo Mixto CONACyT - Gobierno del Estado de Hidalgo) and CONACyT Ciencia Básica n ${ }^{\circ} 167514$. Berenice Peláez and Erika Salgado are thanked for their assistance during fieldwork. Juan Cedillo of the company Tecnoarcillas (Tulancingo, Hgo.) is thanked for providing access to the mines.

\section{REFERENCES}

Aparicio P., Galán E. \& Ferrell R.E. (2006) A new kaolinite order index based on XRD profile fitting, Clay Minerals, 41, 811-817.
Baioumy H.M. (2014) Ti-bearing minerals in sedimentary kaolin deposits of Egypt. Applied Clay Science, 101, 345-353.

Canet C., Arana L., González-Partida E., Pi T., ProlLedesma R.M., Franco S.I., Villanueva-Estrada R.E., Camprubí A., Ramírez-Silva G. \& LópezHernándezA. (2010) A statistics-based method for the short-wave infrared spectral analysis of altered rocks: An example from the Acoculco Caldera, Eastern Trans-Mexican Volcanic Belt. Journal of Geochemical Exploration, 105, 1-10.

Canet C., Hernández-Cruz B., Jiménez-Franco A., Pi T., Peláez B., Villanueva-Estrada R.E., Alfonso P., González-Partida E. \& Salinas S. (2015) Combining ammonium mapping and short-wave infrared (SWIR) reflectance spectroscopy to constrain a model of hydrothermal alteration for the Acoculco geothermal zone, Eastern Mexico. Geothermics, 53, 154-165.

Chakravorty A.K. \& Ghosh D.K. (1991) Kaolinitemullite reaction series: The development and significance of a binary aluminosilicate phase. Journal of the American Ceramic Society, 74, 1401-1406.

Cheary R.W. \& Coelho A.A. (1992) A fundamental parameters approach to X-ray line-profile fitting. Journal of Applied Crystallography, 25, 109-121.

De Pablo-Galán L. (1979) The clay deposits of Mexico. Pp. 475-486 in: Proceedings of the VI International Clay Conference 1978. Developments in Sedimentology, 27 (M.M. Mortland and V.C. Farmer, editors). Elsevier, Amsterdam.

Dixon J.B. \& Weed S.B., editors (1989) Minerals in Soil Environments. Soil Science Society of America, Madison, Wisconsin, USA, pp. 797-808.

Frost R.L., Wain D.L., Wills R.A., Musumechi A. \& Martens W. (2006) A thermogravimetric study of the alunites of sodium, potassium and ammonium. Thermochimica Acta, 443, 56-61.

Garcia-Valles M., Hafez H., Cruz-Matias I., Verges E., Aly M.H., Nogues J.M., Ayala D. \& Martinez S. (2013) Calculation of viscosity-temperature curves for glass obtained from four wastewater treatment plants in Egypt. Journal of Thermal Analysis and Calorimetry, 111, 107-114.

Hinckley D.N. (1963) Variability in crystallinity values among the kaolin deposits of the coastal plain of Georgia and South Carolina. Clays and Clay Minerals, 11, 229-235.

Kakali G., Perraki T., Tsivilis S. \& Badoginnis E. (2001) Thermal treatment of kaolin: the effect of mineralogy on the pozzolanic activity. Applied Clay Science, 20, 73-80.

Küçük A. \& Gülaboğlu S. (2002) Thermal decomposition of Şaphane alunite ore. Industrial and Engineering Chemical Research, 41, 6028-6032.

Legorreta-García F., Olvera-Venegas P.N., HernándezCruz L.E., Vergara-Gómez E., Bolarín-Miró A.M. \& Sánchez De Jesús F. (2010) Caracterización y 
separación gravimétrica de arenas de caolín procedente de Agua Blanca de Iturbide, Hidalgo (México). XIX International Conference on Extractive Metallurgy, Saltillo, Coahuila, México, pp. 901-911.

Legorreta-García F., Hernández-Cruz L. \& Mata Muñoz P. (2013) Estudio de la remoción de impurezas de arcillas caoliníticas del estado de Hidalgo (México). Revista Latinoamericana de Metalúrgia y Materiales, 33, 308-315.

López-Hernández A., García-Estrada G., Aguirre-Díaz G., González-Partida E., Palma-Guzmán H. \& Quijano-León J.L. (2009) Hydrothermal activity in the Tulancingo-Acoculco Caldera Complex, central Mexico: exploratory studies. Geothermics, 38, 279-293.

López-Galindo A., Viseras C. \& Cerezo P. (2007) Compositional, technical and safety specifications of clays to be used as pharmaceutical and cosmetic products. Applied Clay Science, 36, 51-63.

Moore D.M. \& Reynolds R.C. Jr. (1997) X-ray Diffraction and the Identification and Analysis of Clay Minerals. Oxford University Press, New York, 378 pp.

Morales G.J. \& Garduño M.V.H. (1984) Estudio tectónicoestructural en el prospecto Huauchinango, Puebla. Internal Report, Instituto Mexicano del Petróleo, Mexico.

Ramachandran V.S., Paroli R.M., Beaudoin J.J. \& Delgado A.H. (2002) Handbook of Thermal Analysis of
Construction Materials. Noyes Publications, Devon, UK, 75 pp.

Saikia N., Bharali D., Sengupta P., Bordolo D., Goswamee R., Saikia P. \& Borthakur P.C. (2003) Characterization, beneficiation and utilization of a kaolinite clay from Assam, India. Applied Clay Science, 24, 93-103.

Schroeder P.A. \& Erickson G. (2014) Kaolin: From ancient porcelains to nanocomposites. Elements, 10, 177-182.

Silva P.S.C., Oliveira S.M.B., Farias L., Fávaro D.I.T. \& Mazzilli B.P. (2011) Chemical and radiological characterization of clay minerals used in pharmaceutics and cosmetics. Clay Science, 52, 145-149.

Smykatz-Kloss W. (1974) Differential Thermal Analysis, Application and Results in Mineralogy. Springer Verlag, New York, 185 pp.

Spectral International Inc. (1994) SWIR Spectral Mineral Identification System and Spectral Database, SPECMINTM, vol. II. Integrated Spectronics, CO, USA.

Vazquez F., Torres L.M., Garza L.L., Martínez A. \& López W. (2009) Mexican kaolin deposit: XANES characterization, mineralogical phase analysis and applications. Materiales de Construcción, 59, 113-121.

White N.C. \& Hedenquist J.W. (1995) Epithermal gold deposits: styles, characteristics and exploration. Society of Economic Geologists Newsletter, 23, 9-13. 